\title{
DIVORCE DUE TO DOMESTIC VIOLENCE IN SINJAI DISTRICT (Perspective Analysis of Islamic Law)
}

\author{
Nazaruddin ${ }^{1}$ \\ Andi Rasdiyanah ${ }^{2}$ \\ Muh. Saleh Ridwan ${ }^{3}$ \\ Kurniati Kurniati ${ }^{4}$ \\ Alauddin State Islamic University Makassar, Indonesia ${ }^{1,2,3,4}$ \\ emailkorespondensi@gmail.com
}

\begin{abstract}
The purpose of this study is to find out the various factors that cause divorce due to domestic violence in Sinjai Regency and to describe how to resolve divorce due to domestic violence in Sinjai Regency and to elaborate on how divorce due to domestic violence is from an Islamic legal perspective. This research is a qualitative descriptive field research, taking place in Sinjai Regency. The approach used is a normative theological approach, a juridical approach and a sociological approach. The data collection obtained in the field with the technique of observation, interviews / interviews and documentation. The collected data is then processed using data reduction analysis, data presentation and conclusion drawing. Furthermore, by linking one of the theories of Islamic law, namely the theory of existence and competence of religious courts, the process of resolving divorce cases due to domestic violence in Sinjai Regency, which in this case is the authorized and entitled institution in resolving it, namely the Sinjai level I religious court, goes through several stages. namely through table I, table II and table III. However, before the plaintiffs and defendants seek justice, the panel of judges first has the obligation to mediate/advise both parties, in which the panel of judges makes every effort to provide the best advice or solution to the plaintiff or defendant. And Islamic law does not legalize violence against wives. Beating a wife who does nusyuz as contained in QS al-Nisa verse 34 should be interpreted as an act to teach a lesson / for obedience, not to hurt or even do violence. The beatings carried out in the case of nusyuz basically should not injure. Meanwhile, the husband's act of hitting his wife until he is injured or the husband's violence against his wife can be declared as nusyuz of the husband against his wife. Furthermore, related to divorce due to domestic violence in Sinjai Regency which is analyzed from the perspective of Islamic law, the researcher connects one of the theories of Islamic law that applies in Indonesia to date, namely the theory of existence and competence of the Sinjai religious court which refers to the compilation of Islamic law or Islamic law. KHI. al-Nisa verse 34 should be interpreted as an act to teach a lesson/to obey, not to hurt or even do violence. The beatings carried out in the case of nusyuz are basically not allowed to injure. Meanwhile, the husband's act of hitting his wife until he is injured or the husband's violence against his wife can be declared as nusyuz of the husband against his wife. Furthermore, related to divorce due to domestic violence in Sinjai Regency which is analyzed from the perspective of Islamic law, the researcher connects one of the theories of Islamic law that applies in Indonesia to date, namely the theory of existence and competence of the Sinjai religious court which refers to the compilation of Islamic law or Islamic law. KHI. al-Nisa verse 34 should be interpreted as an act to teach a lesson/to obey, not to hurt or even do violence. The beatings carried out in the case of nusyuz basically should not injure. Meanwhile, the husband's act of hitting his wife until he is injured or the
\end{abstract}


husband's violence against his wife can be declared as the husband's nusyuz against his wife. Furthermore, related to divorce due to domestic violence in Sinjai Regency which is analyzed from the perspective of Islamic law, the researcher connects one of the theories of Islamic law that applies in Indonesia to date, namely the theory of existence and competence of the Sinjai religious court which refers to the compilation of Islamic law or Islamic law. KHI. The beatings carried out in the case of nusyuz basically should not injure. Meanwhile, the husband's act of hitting his wife until he is injured or the husband's violence against his wife can be declared as nusyuz of the husband against his wife. Furthermore, related to divorce due to domestic violence in Sinjai Regency which is analyzed from the perspective of Islamic law, the researcher connects one of the theories of Islamic law that applies in Indonesia to date, namely the theory of existence and competence of the Sinjai religious court which refers to the compilation of Islamic law or Islamic law. KHI. The beatings carried out in the case of nusyuz are basically not allowed to injure. Meanwhile, the husband's act of hitting his wife until he is injured or the husband's violence against his wife can be declared as the husband's nusyuz against his wife. Furthermore, related to divorce due to domestic violence in Sinjai Regency which is analyzed from the perspective of Islamic law, the researcher connects one of the theories of Islamic law that applies in Indonesia to date, namely the theory of existence and competence of the Sinjai religious court which refers to the compilation of Islamic law or Islamic law. KHI.

Keywords: Divorce; Domestic Violence; Islamic Law

\section{INTORODUCTION}

Marriage is one that is prescribed by Islam, and aims to be forever filled with love and mut ual love. Therefore, the majority of scholars forbid marriage whose purpose is only temporary, at certain times just to let go of lust, such as mut'ah marriage, and so on. ${ }^{1}$

Amir Syarifuddin in his book mentions that the Compilation of Islamic Law in Article 2 says that marriage according to Islamic law is a very strong contract and to obey Allah's commands and carry it out is worship. In addition, the definition according to Law Number 1 of 1974 concerning Marriage in force in Indonesia or the Compilation of Islamic Law has clearly formulated that the purpose of marriage is to form a happy and eternal family (household) based on the One Godhead. ${ }^{2}$

WordAllah SWT. the following QS ar-Rum/30:21:

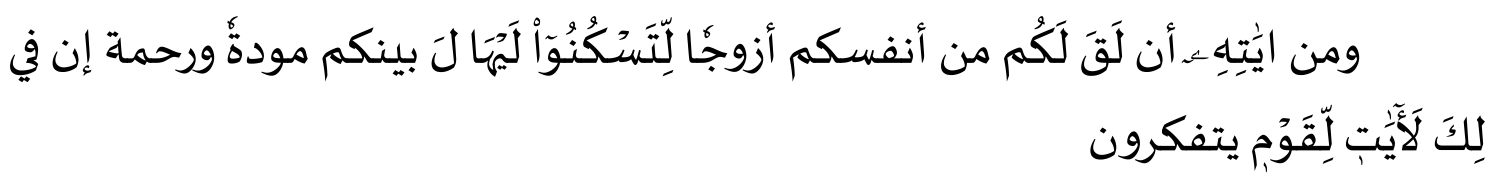

${ }^{1}$ Kamal Mukhtar, Principles of Marriage Law (Jakarta : PT. Bulan Bintang, 1974), p.157.

${ }^{2}$ Amir Syarifuddin, Islamic Marriage Law in Indonesia Between Fiqh Munakahat and Marriage Law (Cet. II; Jakarta: Kencana, 2007), p.40. 
The translation:

"And among the signs of His power is that He has created for you wives of your own kind, so that you may tend to and find peace in them, and He has created between you love and compassion. Verily in that are signs for a people who think." 3

When a woman and a man have agreed to build a household with each other, this means that they promise each other to obey the applicable legal regulations regarding the obligations and rights of each party during and after living together, and manages his position in society from his descendants. ${ }^{4}$

Referring to the results of the initial observations of researchers in the field, in this case the divorce rate in Indonesia, especially in Sinjai Regency, continues to increase, counting from the research data obtained in the last three years from 2017-2019. In 2017 the cases decided by the Sinjai religious court were 237 cases (divorced) and 44 cases (talak divorce), then in 2018, the cases decided by the Sinjai religious court were 255 cases (claimed divorce) and 52 cases (talak divorce). ), and lastly in 2019 the cases decided by the Sinjai religious court were 289 cases (claimed divorce) and 70 cases (talak divorce). ${ }^{5}$

By looking at the divorce rate in the last three years above, the results of the data show that lawsuits are more dominant than divorced divorces, of course this is all motivated by several factors where one of the factors causing the divorce is domestic violence.

Furthermore, with the birth and the issuance of the RI Law No. 23 of 2004 concerning the elimination of domestic violence, this is expected to be a legal umbrella and special protection for victims, especially victims of domestic violence.

UThis law is a guarantee given by the state to prevent domestic violence, take action against perpetrators of domestic violence, and protect victims of domestic violence. ${ }^{6}$ UNor is this domestic violence elimination law aimed at encouraging divorce, as people often claim. The law on the elimination of domestic violence actually aims to maintain a truly harmonious and prosperous household by preventing all forms of violence while protecting victims and taking action against perpetrators of domestic violence.

Therefore, with the increasing divorce rate in the last three years, especially in Sinjai Regency and the RI Law No. 23 of 2004 concerning the Elimination of Domestic Violence, thus making researchers interested in studying and studying a dissertation with the title Divorce due to Domestic Violence households in Sinjai Regency with an analysis of the perspective of Islamic law.

\footnotetext{
${ }^{3}$ Indonesian Ministry of Religion, Al-Qur'an and its Translation (Cet, I; Surabaya: UD Halim, 2017), p. 405.
}

${ }^{4}$ Edy Sumarno. "The Nature of the Marriage Agreement According to Civil Law Relation to Law Number 1 of 1974 concerning Marriage in Indonesia." IUS 3.1 (2015): 19-28.

${ }^{5}$ Data on the Dismissal of the Sinjai Religious Court in 2017-2019

${ }^{6}$ Arifin, Bustanul, and Lukman Santoso. "Protection of Women Victims of Domestic Violence from the Perspective of Islamic Law." De Jure: Journal of Law and Sharia 8.2 (2016): p. 113. 


\section{LITERATURE REVIEW}

\section{A. Definition of Divorce}

Divorce or known in fiqh terms as thalaq, is the termination of a husband and wife relationship, either determined by the judge (called divorce thalaq), or due to the death of his partner (divorce). The word divorce in the Big Indonesian Dictionary comes from the word divorce which means separation.

The second definition is defined as the breakup of a husband and wife relationship. In addition to these two definitions, divorce in the Big Indonesian Dictionary gives another meaning to thalaq divorce, namely living separately between husband and wife while both are still alive, then divorce is defined as separation between husband and wife because one of them dies. ${ }^{7}$

Divorce in Arabic comes from the word لاقا -- لق - لق, thalaqa, yathliqu, thalaaqan which means releasing or unraveling the ropes, whether the ropes are concrete like horse ropes or abstract like marriage ropes. ${ }^{8}$ The word thalaq This itself is used as a letter in the holy book al-Quran, namely the 65th letter which consists of 12 verses, named Surah al-Thalaq because most of the verses are about issues related to and related to thalaq. ${ }^{9}$

Further more, according to the term Syarak, thalaq is:

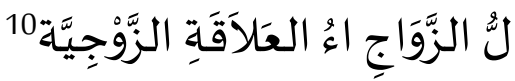

It means :

\section{"Let go marriage and ending the husband and wife relationship."}

In Islam, divorce is likened to the final door in a household that can no longer be maintained. Households that are no longer harmonious and certainly will not find a common ground, the word divorce is the answer. However, even though this divorce is positioned as something that is permissible/halal, the prophet Muhammad saw. Think of it as something that is very hated by Allah swt. This is confirmed by his words, which states that:

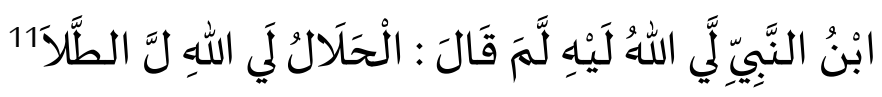

It means:

"From Ibn Umar from the Prophet. : Halal acts that are most displeased by Allah swt. is talaq." (HR. Abu Dawud).

${ }^{7}$ Ministry of National Education, Big Indonesian Dictionary Edition III (Cet. II; Jakarta: Balai Pustaka, 2002), p. 278.

${ }^{8}$ Syaerifuddin Latif, Marriage Law in Indonesia book 2 (Cet. I; Jakarta: CV. Berkah Utami, 2010), p. 37.

${ }^{9}$ Zaitunah Subhan, Initiating Fiqh on Women's Empowerment (South Jakarta: el-Kahfi, 2008), p. 234.

${ }^{10}$ Sayyid Sabiq, Fiqh al-Sunnah, Volume II (Bairut: Dar al-Fikr, 1983), p. 206

${ }^{11}$ Abu Dawud, Sunan Abu Dawud Juz I (Bairut: Dar al-Fikr, t. th), p. 661. 
This hadith is a proof that among the halal there are those who are angry with Allah swt. if it is not used properly and the perpetrator is most displeased without a reason justified by the act of divorce. Divorce has no reward and cannot be seen as an act of worship. This hadith is also the legal basis that husbands must always abstain from the practice of divorce while there is still a way to avoid it. The husband is only justified in dropping a divorce if he has to, there is no other way to avoid it, and divorce is one way to create benefit.

\section{B. Reasons that Permit Divorce in Islamic and National Law}

In the case of thalaq, the party who proposes is the husband, while the party who proposes divorce is the wife. As stated in the Compilation of Islamic Law article 114 that: "The breakup of a marriage caused by divorce can occur because of thalaq or based on a divorce lawsuit". ${ }^{12}$

Islamic Shari'ah provides the possibility for husbands and wives to apply for divorce to the Court, when circumstances arise that do not provide comfort in their married life. This situation makes him suffer because there is no longer compatibility in the household, so he can no longer bear to continue the marital bond that exists between husband and wife. In these circumstances, and in order to relieve suffering, Islamic Shari'ah gives the right to sue for divorce to the Court. The reasons according to Islamic law are:

1. The reason for divorce is because the partner commits adultery

2. The reason for the divorce is due to illness or disability

3. The reason for divorce is because of the act of hurting / molesting a partner

4. Because there is no livelihood

Allah SWT. explains some of the efforts that must be made to deal with this crisis so that divorce does not occur, so God anticipates the possibility of divorce and places divorce as the last alternative that is unavoidable.

Divorce will not occur if various household and family problems can be handled wisely, such as economic problems, honesty with one another and so on. Because in the household, anyone will experience various problems, both internal and external factors, severe or minor, which cause disharmony in the form of quarrels and differences with each other which leads to acts of domestic violence.

The inability to solve problems that afflict the family, is more influenced by the immaturity of each other's attitudes and personality, excessive egoism and does not want to accept suggestions from other parties (parents), divorce as a lawful act however, is not liked by God because it has negative impacts for both parties and their offspring, these impacts include psychological, moral, social and economic.

\section{METHOD}

This research is a qualitative descriptive field research, taking place in Sinjai Regency. The approach used is a normative theological approach, a juridical approach and a sociological approach. The data collection obtained in the field with the technique

\footnotetext{
${ }^{12}$ Marriage Law (UU No. 1 of 19974), (Surabaya: Rona Publishing), p. 137.
} 
of observation, interviews / interviews and documentation. The collected data is then processed using data reduction analysis, data presentation and conclusion drawing.

\section{RESULTS AND DISCUSSION}

In this section, it will be explained related to the analysis of the meaning of hadith on environmental pollution and its solutions.

\section{A. The Situation of the Case at the Sinjai Religious Court in 2017-2019}

From the data contained in the table above, information is obtained that in 2017 the Sinjai Religious Court accepted 248 cases of divorce (divorce filed by the wife), but only 237 cases were decided, meaning there were 11 cases that had information. revoked, terminated and rejected. Furthermore, the case for talak divorce (divorce submitted by the husband) The Sinjai Religious Court received 51 cases and 44 cases were decided, this means that there are 7 cases that have information revoked, dropped or rejected. For other cases, information was obtained in 2017 that the two most petitioned cases were marriage certificates, 234 cases were accepted and 218 cases were decided. and marriage dispensation as many as 63 cases were accepted and 58 cases were decided. Furthermore, looking at the third data mentioned above, regarding the various factors causing divorce at the Sinjai Religious Court in 2017, it can be seen that there were 19 cases of moral crisis, 89 cases of lack of responsibility, 144 cases of lack of harmony and factor punished 1 case.

From the data obtained, it is stated that in 2018 the Sinjai Religious Court accepted 280 cases of divorce (divorce submitted by the wife), but only 255 cases were decided, meaning there were 25 cases that had information revoked, dropped or rejected. Furthermore, the case of talak divorce (divorce submitted by the husband) The Sinjai Religious Court received 63 cases and 52 cases were decided, this means that there were 11 cases that had information revoked, dropped or rejected. For other cases, information was obtained in 2018 that the two most petitioned cases were marriage certificates of 211 cases which were accepted and decided as many as 196 cases, and marriage dispensation as many as 78 cases received and 64 cases decided.

From the data contained in the table above, information is obtained that in 2019 the Sinjai Religious Court accepted 311 divorce cases (divorce filed by the wife), and 289 cases were decided, meaning there were 22 cases that had information revoked., dropped or rejected. Furthermore, the case of talak divorce (divorce submitted by the husband) The Sinjai Religious Court received 85 cases and 70 cases were decided, this means there are 15 cases that have information revoked, dropped or rejected. For other cases, information was obtained in 2019 that the two most petitioned cases were marriage certificates of 172 cases which were accepted and 136 cases were decided. and 131 cases of marriage dispensation were accepted and 120 cases were decided. Furthermore, looking at the third data mentioned above, regarding the various factors causing divorce at the Sinjai Religious Court in 2019, it can be seen that the moral crisis factor was 38 cases, the economic factor was 1 case, the irresponsibility factor was 113 cases, There are 5 cases of physical cruelty, 1 case of punishment, 4 cases of biological disability, 181 cases of lack of harmony, 6 cases of third party interference, 4 cases of unhealthy polygamy, 2 jealousy factors, the factor of forced marriage is 1 case and finally the other factor / apostasy there is 1 case. 
Looking at the data for the last three years from 2017-2019, the factors that cause divorce at the Sinjai religious court level I are related to domestic violence, the number of cases that have been decided by the researcher is detailed as follows:

1. 2017
a. $\quad$ Physical Violence $=$ Nothing
b. Psychic Violence $=$ Nothing
c. Sexual Violence $=$ Nothing
d. Economic Violence $=89$ Cases

2. 2018
a. Physical Violence $=6$ Cases
b. Psychic Violence $=$ Nothing
c. Sexual Violence $=$ Nothing
d. Economic Violence $=99$ Cases

3. 2019
a. Physical Violence $=5$ Cases
b. Psychic Violence $=4$ Cases
c. Sexual Violence $=$ Nothing
d. Economic Violence $=113$ Cases

Therefore, the total number of divorce cases that have been decided due to domestic violence in Sinjai district in the last three years is 316 cases.

\section{B. Various Factors Causing Domestic Violence in Sinjai District}

The factors that cause divorce due to domestic violence in the Sinjai Religious Court are caused by several factors including the lack of knowledge and understanding of religion by both parties, economic factors, infidelity or the presence of a third party, moral/moral crisis factors (drinks and gamblers). ), constant disputes and squabbles. Therefore, an assessment of various factors that indicate an act of domestic violence by analyzing 4 cases that occurred in 2019-2020 with the decision Number 200/Pdt. G/2019/PA. Sj. On June 25 2019, decision Number 399/Pdt. G/2019/PA. Sj. On December 10, 2019, decision Number 209/Pdt. G/2019/PA. Sj. February 18, 2019 and decision Number 1/Pdt. G/2020/PA. Sj January 23, 2020

\section{Divorce Settlement Due to Domestic Violence in the District}

The settlement of divorce due to domestic violence in Sinjai Regency according to Nasrun, S.Ag. as the Secretary of the Sinjai Religious Court that the case settlement process is no different from the Religious Courts or the Courts of first instance, based on the procedure for administering case administration. Including divorce cases due to domestic violence are processed according to applicable procedures. ${ }^{13}$

The procedure for resolving cases at the Religious Courts is as follows: Justice seekers go to the Religious Courts to submit their cases for further processing. By linking one of the theories of Islamic law, namely the theory of existence and absolute competence of the religious courts, the process of resolving divorce cases due to

\footnotetext{
${ }^{13}$ Nasrun, Secretary of the Sinjai Religious Court, Interview at the Sinjai Religious Court, 18 February 2020
} 
domestic violence in Sinjai Regency, which in this case is the authorized and entitled institution in resolving it, namely the Sinjai level I religious court, goes through several stages. namely through table I, table II and table III.

However, before the plaintiffs and defendants seek justice, the panel of judges first has the obligation to mediate/advise both parties, in which the panel of judges makes every effort to provide the best advice or solution to the plaintiff or defendant. The stages that are passed are table I, table II and table III. The definition of the table is a group of technical implementers that must be passed by a case in a religious court, starting from acceptance until the case is resolved.

\section{Divorce Due to Domestic Violence in Sinjai Regency Islamic Law Perspective}

The location of the urgency of this research is the generalization of the word "violence" in the household, so that it seems that in the household there should be no violence at all even though the violence is a form of carrying out the obligations of the person in charge of the family (husband) in carrying out his obligations in order to maintain the family's rails in the family. the line of Allah's blessing.

In sinil It requires an in-depth analysis of domestic violence, whether all types of violence must be abolished without a clear line, a husband may be firm and take strong action against syar'i violations that occur in the household in accordance with his authority or obligations. While Islamic law is prescribed not empty of content, but full of wisdom, it is prescribed for a law. One of the wisdoms of allowing a husband to 'give a lesson' to his wife is that she should always be under the control of her husband in order to obey Allah swt. and his apostles. This mattermeant unto avoid nusyuz and the symptoms that lead to it. ${ }^{14}$

Islamic law in dealing with domestic violence issues is more focused on the problem of nusyuz between husband and wife and the issue of withdrawing al-shalah for children who are 10 years old after being taught to pray by their guardians since he was seven years old. As for the harsh actions of the husband against the maid, for example due to the careless act of the maid, no reference has been obtained to be analyzed in Islamic law as long as it is not a criminal offense which is handed over to the authorities in handling.

Domestic violence is an act that is prohibited in Islam. Domestic violence can happen to anyone and in any form, because Islam it self always teaches gentle behavior and compassion among others. Islam does not recognize the term or definition of domestic violence specifically. In fact, Islamic teachings strictly prohibit the occurrence of domestic violence. This is evidenced by the many verses in the Qur'an and al-Hadith that instruct husbands to treat their wives with good relationships. As the word of Allah swt state:

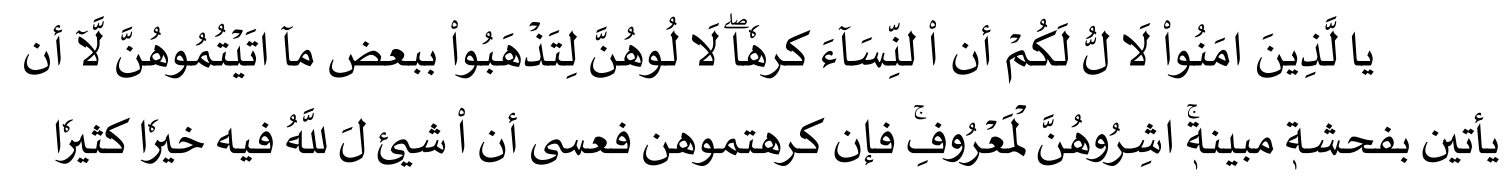

The translation:

"O you who believe, it is not lawful for you to inherit women by force and do not trouble them because they want to take back some of what you have given them, unless they do a real heinous job. And get along with them properly, then if you don't like

\footnotetext{
${ }^{14}$ Shaykh 'Alî Ahmad al-Jurjâwî, Hikmat al-Tasyr' wa Falsafatuhu, Volume 2 (Cairo, Jâmi'ah alAzhar, t.th), p.43.
} 
them, (then be patient) because maybe you don't like something. Yet Allah made him much good." (Surah An-Nisa 4:19).

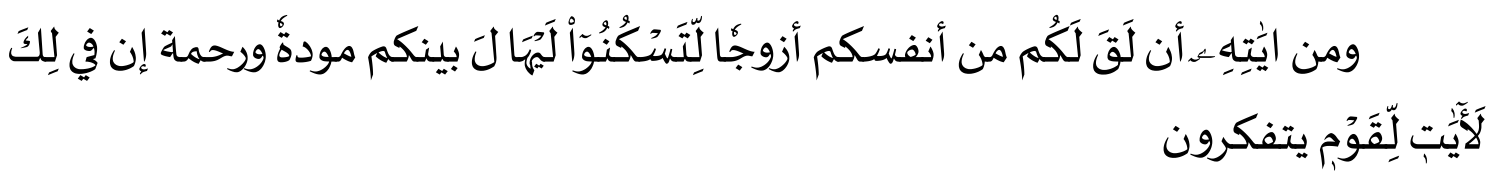

The translation:

"And among the signs of His power is that He has created for you wives of your own kind, so that you may tend to and find peace in them, and He has created between you love and compassion. Verily in that are signs for a people who think." (Surah ArRum 30:21).

The verse above explains the command to treat the wife well. Besides that, the Prophet also emphasized the issue of compassion and protection and that compassion is part of protection and protection is part of compassion. Compassion is a broader concept that can include various human values that originally were protection.

1. Rights and Duties of Husband and Wife in Islam

The concept of family life in Islam places all family members in portions and positions that are in accordance with their respective natures. The husband as the head of the family has greater rights than the wife in accordance with her obligations, which occupies the most positions. Likewise, a wife has the same rights and obligations according to her nature as a woman. A child also has the right to be loved but also has an obligation to respect his parents.

Proportionality This is as illustrated by the general hadith of muttafaq alayh narrated by ibn 'Umar below:

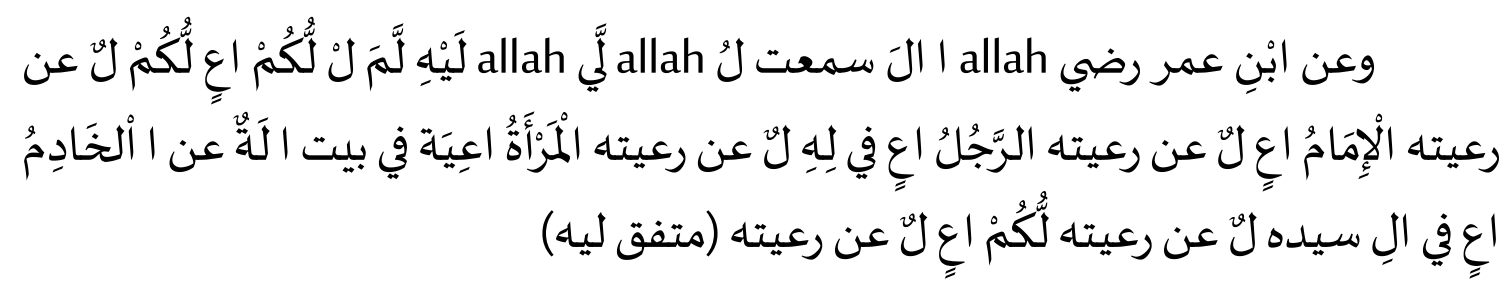

It means:

"From Ibn 'Umar ra. He said: I heard the Messenger of Allah. Bersabda: each of you is a leader and will be askedwha ertan responsibility for his leadership, an imam is mobile phone dreamn and will be held accountable for his people, men are leaders in their families and will held accountable for her family, a womann ais a keeper in tan's housegga husbandyes and will be asked responsibility for its care, and a maid is guardian of his master's property and will be held accountable or That's his guard. Each of you is a leader and will be asked accountability for his leadership." (Narrated by Bukhari-Muslim). ${ }^{15}$

From the generality of the hadith, it can be understood that every family member has the same rights and obligations as well as responsibilities according to their

\footnotetext{
${ }^{15}$ Abî Zakariyâ Muhy al-Dîn Yahya al-Nawâwî, Riyâdl al-Shâlihîn, (Surabaya: Darul Ulum, t.th.), p. 158
} 
respective portions and positions. Not allowed when askingtreatment which exceeds their rights and obligations.

One of the rights of a husband is to get proper respect and obedience from family members regarding the role of the head of the household and to be responsible both morally, materially and spiritually in upholding the teachings of Allah swt. Thereforeobligation a husband includes things that are material worldly and spiritual hereafter. ${ }^{16}$

The husband's material obligations include providing a decent living according to the size of his ability to his children, wife, and members family which is his responsibility. Not appropriate according to the size of the community in which he lives. The livelihood includes board clothing and food. His mental spiritual obligation is to provide guidance to his wife and children and other family members to always obey Allah's commands and his messenger. ${ }^{17}$

Including the moral obligation of a husband is to give a warning and even a proper and educational punishment for his family members who violate the rules of Allah swt. and His rasûl. He is obliged to 'beat' his wife who is nusyûz and his child who is pulling al-shalâh after the child is ten years old and he has carried out his obligation to teach prayer since the child was seven years old.

A wife has the right to receive physical and spiritual support from her husband and is entitled to self-protection and honor from her husband, including getting an education that is in accordance with her husband's ability if he still needs it. While her obligation is to obey her husband either willingly or by compulsion as long as her husband is still standing in the corridor of Allah's pleasure. And a wife is obliged to be an assistant to her husband when the husband is not at home where he lives.

\section{Nusyuz According to Islamic Law}

The word Nusyuz is a masdar form of the word nasyaza which means land that sticks up high. Meanwhile, terminology, nusyuz has several meanings including:

a. Fuqaha Hanafiyya defines it by the displeasure that occurs between husband and wife

b. The Malikiyah jurists give the definition of nusyuz as enmity that occurs between husband and wife;

c. Side disha Syafi'iyyah, nusyuz is a dispute that occurs between husband and wife;

d. Side disha Hambaliyah defines it as displeasure from the wife and husband accompanied by disharmony. ${ }^{18}$

Meanwhile, nusyuz from the husband's side towards his wife, according to Hanafi clerics, is in the form of the husband's hatred for his wife and abusing her. Fuqaha Malikiyah defines it as the attitude of a husband who is hostile to his wife, besides that

\footnotetext{
${ }^{16}$ Wahed, Abd. "Analysis Islamic Law on the Problem of Domestic Violence (KDRT)." Al-Ihkam: Journal of Law and Social Institutions 4.1 (2013): p. 31

${ }^{17}$ Hidayatulloh, Harris. "Rights and Duties of Husband and Wife in the Qur'an." Journal of Islamic Family Law 4.2 (2020): p. 143.

${ }^{18}$ Salih bin Ghanim al-Sadlani, Nusyuz, Husband and Wife Conflict and its Resolution, trans. Muhammad Abdul Ghafar, (Jakarta: Pustaka al-Kautsar, 1993), p. 26.
} 
he also hurts her either by hijr or beatings that are not allowed by syara', insults and so on. ${ }^{19}$

Side disha Syafi'iyah defines it as the attitude of a husband who antagonizes his wife with beatings and other acts of violence and acts unkindly towards her. Meanwhile, the Hambali cleric defines it as the harsh treatment of a husband against his wife by hitting and cornering or not giving his wife the rights such as the right to a living and so on. ${ }^{20}$

Downt Hanafi scholars are the wife leaving the house without her husband's permission and closing herself off to her husband, even though she has no right to do so. According to Malikiyah scholars, nusyuz is the wife's exit from the lines of obedience that has been required, forbidding her husband to have fun with her, leaving the house without the husband's permission because he knows that his husband will not allow it, leaving Allah's rights such as not wanting to take a bath, prayer and fasting in Ramadan and closing all doors for her husband. ${ }^{21}$

Down According to the Syafi'iyah scholars, nusyuz is the wife's disobedience to her husband and the violations committed against the provisions that are required by Allah swt. to him. Hambaliyah scholars define it as a violation by a wife against her husband on the provisions that are required of him from the rights of marriage. ${ }^{22}$

3. Implication Nusyuz Law in Islam

In treasuryh fiqh the issue of nusyuz is regulated in QS al-Nisa' verse 34, in that verse Allah swt. said:

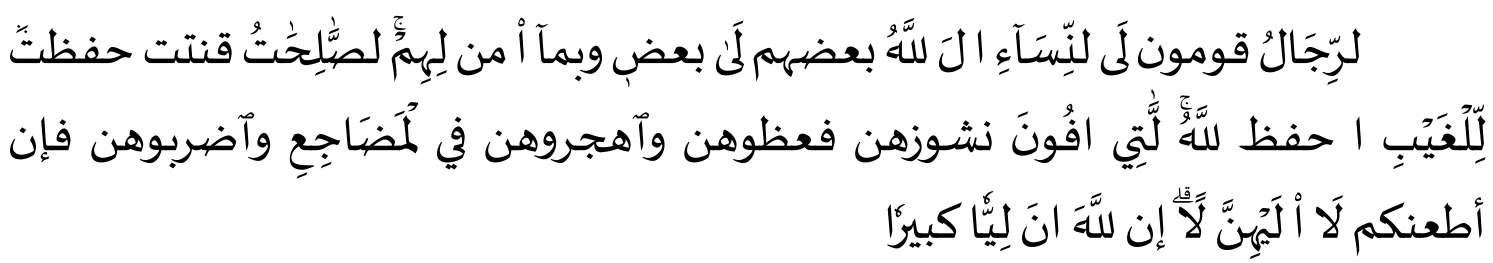

The translation:

"The men are the leaders for the women, because Allah has favored some of them (men) over others (women), and because they (men) have spent part of their wealth. Therefore, a righteous woman is one who is obedient to Allah and takes care of herself when her husband is not around, because Allah has taken care of (them). The women for whom you are concerned about their nusyuz, then advise them and separate them in their beds, and beat them. Then if they obey you, then do not look for ways to trouble them. Verily Allah is Most High, Most Great."23

${ }^{19}$ sawqi,AbdulHaq. "Islamic Law and Domestic Violence." Journal de Jure 7.1 (2015) p. 68

${ }^{20}$ Zainuddin Ibn Najm al Hanafi, al-Bahr al-Raiq Volume 6, (Pakistan: Karachi, t.th.), p. 78.

${ }^{21}$ Zainuddin Ibn Najm al Hanafi, al-Bahr al-Raiq Volume 6, (Pakistan: Karachi, t.th.)

${ }^{22}$ Salih bin Ghanim al-Sadlani, Nusyuz, Husband and Wife Conflict and its Resolution, trans. Muhammad Abdul Ghafar, (Jakarta: Pustaka al-Kautsar, 1993), p. 26-27 108.

${ }^{23}$ DepRI Religious Artement. Al-Qur'an and its translation, (Surabaya: PT. Mahkota, 2017), pp. 
Related With this verse, Tafsir Jalalain explains that men are leaders, namely those who control women, teach them and protect them, because of what Allah swt has exaggerated. to some of them over others, such as advantages in terms of knowledge, reason and guardianship, and so on, and the wealth they spend. ${ }^{24}$

MTo complete the explanation above, al-Jurjâwî emphasized that the obligation to teach his wife a lesson is when she begins to disobey andshowan gelaja nusyûz to husband. So the husband is obliged to give lessons, but the giving of these lessons is carried out in the order that first the husband is obliged to give a warning to his wife gently and gently like reminding her to fear Allah when the wife is obedient again, then it is enough just to get there.If stillIf $h$ persists, then leave the wife alone, by leaving her in bed, not gathering her, especially when her lust is at its peak. If he is obedient, then just get there and gather the wife as usual. However, if it persists, then the wife may be 'hit' with a note that it is not too hard and does not cause injury. ${ }^{25}$

Based ont he verses and Hadiths above, it can be concluded that it is permissible to beat the wife if she commits nusyuz. However, the above verse must be understood comprehensively. That for women who are afraid to commit nusyuz, then first advise them, then separate their beds and finally they can be beaten. This verse also begins with the statement that men are leaders for women'. According to al-Jassas, lafadz qawwam is intended as a person who must teach manners or make it civilized, take care of it, and take care of it. So, Allah has favored men over women, both in terms of reason, as well as in the income given to women.

Morecontinued al-Jassas explaining that regarding the treatment of the husband for the first time when his wife did nusyuz, namely advising him. Then remind him to fear Allah and His punishment. The third step is to separate the bed. There are several opinions about separating beds, namely separating them by language or isolating them with words, leaving jima' or not having sex with them, and separating beds. The last step taken after the three methods above did not work, namely hitting him.

If the wife has returned to obey her husband after being separated from the bed, then it is no longer permissible to be beaten. In a narration it is explained that fear Allah against women because you all have taken them as a trust from Allah and made lawful for you their honor (intercourse) with the word of Allah, and for you so that your wives do not commit jima' with other men that you do not like in the world. bed, then hit your wives with a blow that does not cause injury, and your wives are entitled to sustenance and good clothes. ${ }^{26}$

Dithm Understanding the analysis of the two scholars above, it can be understood that the beating of a husband against a wife who is nusyûz is more of a husband's obligation to educate his wife to always obey Allah, not an act of violence that must be abolished. Because then sunnatullâh in married life as husband and wife is likened to an ark where the husband is the captain and the wife is the na'ib to form a sakinah family, mawaddah warahmah will be achieved. ${ }^{27}$

\footnotetext{
${ }^{24}$ Jalâl al-Dn al-Sayûthî, Tafsr Jalâlayn, Volume 2 (Bandung: al-Ma'arif, t.th.), p. 86.

${ }^{25}$ Al-Jurjâwî, Hikmat al-Tasyrî,'h.. 43.

${ }^{26}$ Narrated by Ja'far bin Muhammad from his father, from Jabir bin Abdillah, Imam al-Jassas, Tafsir...h. 268-269.

${ }^{27}$ Sri Wahyuni,. "The Concept of Nusyu ${ }^{-} \mathrm{Z}$ and Violence Against Wives: A Comparison of Positive Law and Fiqh." al-Ahwal: Journal of Islamic Family Law 1.1 (2016) p. 17-30.
} 
Different This is the case with the freedom that is propagated by non-Muslims, where it is more aimed at destroying the sunnatullah, so that the society formed is a society that is value-free and aims at freedom as freely as possible.

4. Reinterpretation of the text of QS al-Nisa' paragraph 34 and the Purpose of the PKDRT Law

One of the verses of the Qur'an which is often considered not to defend women is al-Nisa' verse 34, which states that men are the leaders for women, and legalizes the beating of husbands when wives commit nusyuz. This verse is often used as an excuse to support patriarchal culture, namely that men are leaders for women both in society in general and in the household.

In Tafsir al-Mizan, it is stated that the words rijal and nisa' in the verse are not general in nature, namely male and female. However, men and women in their relationship in the household, namely husband and wife. Because the verse also describes women who are pious women who take care of themselves when their husbands are not around... and so on, as well as the actions of men when women do nusyuz. So, men and women in this context are husband and wife in the household. ${ }^{28}$

In line with the opinion above, Asghar Ali Engineer also stated that the context of the verse is limited only to the household. According to him normatively, indeed the Qur'an places men in a superior position to women. However, the Qur'an does not assume or state that social structure is normative.

ah social structure is uncertain and indeed is always changing, and if in a social structure where women support their families, or become friends with men, women must be equal or even superior to men and play a dominant role in their families as played by men. ${ }^{29}$

As for the permissibility of beatings in the verse, it can be understood based on the special events that led to the revelation of the verse (asbab an-nuzul). That is, the verse was revealed after a man injured his wife, and then his brother complained to the Messenger of Allah, so he ordered him to do qishas.DIn the narration of Ibn Murdawayh, it is stated that a friend of Ansar slapped his wife until she left a mark. Then the wife complained to Raslullâh, and he forbade doing so, then came down verse 34 of the letter al-Nisa 'this. ${ }^{30}$

Based on the asbab al-nuzul above, it can be understood that the verse is indeed in the context of a household, and beatings were allowed at that time to cancel the Prophet's decision about qishas. However, beatings in this case should be interpreted to teach lessons, not to hurt and injure the wife.

\footnotetext{
${ }^{28}$ Sayyid Muhammad Husain at-Tabataba'i, al-Mizan fi at-Tafsir, Volume IV (Lebanon: al-Alami, t.th), p. 343-346.

${ }^{29}$ Asghar Ali Engineer, Islam and Liberation Theology, trans. Agung Prihantoro (Yogyakarta: Student Library, 1999), p. 237.

${ }^{30}$ Abû Bakr al-Sayûthî, Lubab al-Nuqul fî̀ Asbâb al-Nuzul (Hamisy Tafsîr Jalâlayn), vol. 1 (Bandung: Al-Ma'arif, tt), p. 92.
} 


\section{CONCLUTION}

The conclusions from all previous discussions are: 1) Various factors that cause divorce due to domestic violence in Sinjai district, including the following: lack of knowledge and good understanding of religious teachings or Islamic and national law, in addition there are factors of continuous disputes that lead to fights and beatings, economic factors, third party interference factors and other factors, namely a moral/moral crisis (alcohol/drinking addicts). violence, gambling), as for the forms of violence committed in the last three years, namely physical violence with a total of 11 cases, psychological violence with a total of 4 cases, and economic violence or neglect of households with the highest number of 301 cases. 2) The process of resolving divorce cases due to domestic violence in Sinjai Regency, which in this case has the authority and has the right to resolve it, namely the Sinjai religious court level I, goes through several stages, namely through table I, and table III. However, before the plaintiffs and defendants seek justice, the panel of judges first has the obligation to mediate/advise both parties, in which the panel of judges makes every effort to provide the best advice or solution to the plaintiff or defendant. 3) Hsizem Islam does not legalize violence against wives. The beating of a wife who does nusyuz as contained in QS al-Nisa verse 34 should be interpreted as an act to teach a lesson / for obedience, not to hurt or even do violence. The beatings carried out in the case of nusyuz basically should not injure. Meanwhile, the husband's act of hitting his wife until he is injured or the husband's violence against his wife can be declared as the husband's nusyuz against his wife.Furthermore, related to divorce due to domestic violence in Sinjai district which is analyzed from the perspective of Islamic law, the researcher connects one of the theories of Islamic law that applies in Indonesia to date, namely the theory of existence and competence of the Sinjai religious court which refers to the compilation of Islamic law or Islamic law. KHI. The theory of existence itself was put forward by SA Ichtijanto. He explained that the theory of existence in relation to Islamic law is a theory that explains the existence of Islamic law in Indonesian national law.

\section{BIBLIOGRAPHY}

Al-Nawâwî, Abî Zakariyâ Muhy al-Dîn Yahya Riyâdl al-Shâlihîn, Surabaya: Darul Ulum, t.th.

Arifin, Bustanul, and Lukman Santoso. "Perlindungan Perempuan Korban Kekerasan Dalam Rumah Tangga Perspektif Hukum Islam." De Jure: Jurnal Hukum dan Syari'ah 8.22016

Asghar Ali Engineer, Islam dan Teologi Pembebasan, terj. Agung Prihantoro Yogyakarta: Pustaka Pelajar,1999

Departemen Agama RI. Al-Qur'an dan Terjemahnya, Surabaya: PT. Mahkota, 2017, 
Hidayatulloh, Haris. "Hak Dan Kewajiban Suami Istri Dalam Al-Qur'an." Jurnal Hukum Keluarga Islam 4.22020

Kamal Mukhtar, Asas-asas Hukum Perkawinan Jakarta : PT. Bulan Bintang,1974

Kementrian Agama RI, Al-Qur'an dan Terjemahnya Cet, I; Surabaya: UD Halim, 2017

Sayyid Muhammad Husain at-Tabataba'i, al-Mizan fi at-Tafsir, Jilid ivlebanon: alAlami, t.th

Shaleh bin Ghanim al-Sadlani, Nusyuz, Konflik Suami Isteri dan Penyelesaiannya, terj. Muhammad Abdul Ghafar, Jakarta: Pustaka al-Kautsar, 1993

Sumarno, Edy. "Hakekat Perjanjian Kawin Menurut Hukum Perdata Kaitannya Dengan Undang-undang Nomor 1 Tahun 1974 Tentang Perkawinan Di Indonesia." IUS 3.12015

Syarifuddin, Amir Hukum Perkawinan Islam di Indonesia Antara Fiqh Munakahat dan Undang-Undang Perkawinan Cet. II; Jakarta: Kencana, 2007

Syawqi, Abdul Haq. "Hukum Islam dan Kekerasan dalam Rumah Tangga." Journal de Jure 7.12015

Syaykh 'Alî Ahmad al-Jurjâwî, Hikmat al- Tasyrî' wa Falsafatuhu, Jilid 2 Kairo, Jâmi'ah al-Azhar, t.th

Wahed, Abd. "Analisis Hukum Islam terhadap Masalah Kekerasan Dalam Rumah Tangga (KDRT)." Al-Ihkam: Jurnal Hukum dan Pranata Sosial 4.1 2013

Wahyuni, Sri. "Konsep Nusyu Z Dan Kekerasan Terhadap isteri: Perbandingan Hukum Positif dan Fiqh." al-Ahwal: Jurnal Hukum Keluarga Islam 1.1 (2016): 17-30.

Zainuddin Ibn Najm al Hanafi, al-Bahr al-Raiq Jilid 6, Pakistan: Karachi 